\title{
Bioethanol Production From Hassawi Rice Straw Wastes Assisted by Aspergillus sp. NAS51 Cellulosic Enzyme Under SSF and Saccharification Process With in Silico Enzyme Structural Homology Modeling
}

Ahmed Ahmed Abdelghani Hamed Abdalla Shalabi ( $\nabla$ ahmedshalbio@gmail.com )

National Research Center Inc https://orcid.org/0000-0002-9997-9284

Hala A. Ibrahim

King Khalid University

Mohamed Khedr

Al-Azhar University

Mona Shaban E. M. Badawy

Al-Azhar University

Saad Alamri

King Khalid University

Mohammad Y. Alfaifi

King Khalid University

Ali A. Shati

King Khalid University

Serag Eldin I. Elbehairi

King Khalid University

Hisham S.M. Abd-Rabbo

King Khalid University

Khalid F. Fawy

King Khalid University

Mohamed S. Hamdy

King Khalid University

Nasser S. Awwad

King Khalid University

Research Article

Keywords: Bioethanol, rice straw, Aspergillus sp. NAS51, cellulase, Saccharification, homology modeling 
Posted Date: December 28th, 2021

DOI: https://doi.org/10.21203/rs.3.rs-1100144/v1

License: (c) (i) This work is licensed under a Creative Commons Attribution 4.0 International License. Read Full License 


\section{Abstract}

With the distribution of exploitable non-renewable energy resources, the use of lignocellulosic wastes to make bioethanol and biogas has drawn great attention from researchers. In our effort to find a potent cellulase-producing fungal strain, the fungus NAS51 was isolated from a sponge collected from the Red Sea, Jeddah, among eight isolates and selected as it displayed potent cellulolytic activity. The fungus was identified morphologically and genetically by sequencing its 18SrRNA gene as Aspergillus sp. NAS51. The cellulase activity of Aspergillus sp. NAS51 was optimized and maximum enzyme production was obtained at initial $\mathrm{pH} 7$, temp $30^{\circ} \mathrm{C}$, incubation period 11 days, moisture content $70 \%$, urea as a nitrogen source, and $\mathrm{K} 2 \mathrm{HPO} 4(2 \mathrm{~g} / \mathrm{L})$. The cellulase gene has been sequenced and the protein 3D structure was generated via in silico homology modeling. Determination of binding sites and biological annotations of the constructed protein was carried out via COACH and COFACTOR based on the ITASSER structure prediction. To reach the maximum enzyme hydrolysis, the rice straw collected from AlAhsa, Kingdom of Saudi Arabia was pretreated with $\mathrm{NaOH} 1.5 \%$ to remove lignin and to enhance the saccharification process by cellulase enzyme. The saccharified product was measured using HPLC, fermented by S. cerevisiae and the bioethanol yield produced from the fermentation was $0.454 \mathrm{ml}$ ethanol/g fermentable sugars.

\section{State Of Novelty}

Over the last 20 years, the increasing prices of fossil fuels have made the rely on biofuels reach unprecedented levels. In his work, we describe the production of bioethanol from lignocellulosic wastes using a novel fungal strain as an alternative strategy. This alkali-pretreatment of the lignocellulosic straw improved the release of glucose and fermentation by yeast for bioethanol production. Additionally, the determination of binding sites and biological annotations of the cellulase enzyme will help to maximize the utilization of this enzyme in the forthcoming future.

\section{Introduction}

Energy is undoubtedly one of the major challenges in the development of any country. The term 'Bioenergy' is one of a variety of resources that can supply and cover our energy demand. It is a type of renewable energy such as bioethanol and biogas which is generated from organic materials known as biomass that can be used in the production of fuels, heat, electricity, and products [1]. Renewable energy produced from the use of lignocellulosic raw material such as rice straw and husk has become an alternate fuel to the existing fossil fuels throughout recent decades. These renewable raw materials are viable biomass for creating many high-value products, such as biogas, gasoline, and biodiesel [2]. Rice straw is a common lignocellulosic waste of the rice manufacturing process. It is the second great bioresource lignocellulosic waste material in the world. Rice straw ranked as one of the major agricultural wastes in the world with approximate dry lignocellulosic biomass resulted from rice production of 905 million tonnes each year. In Egypt only, 4 million tons of rice straw are estimated to be produced each year. Rice straw is mostly composed of (cellulose 32-47\%), (hemicelluloses 19-27\%), (lignin 5-24\%), and ( 
ashes 18.8\%) [3]. At any energy bioconversion process, lignocellulosic biomass pretreatment increases the biodegradation rate and overall primary product yield. The fact that most biomass contents are (carbohydrates, lipids, and proteins) enables some microbes under the anaerobic digestion process to convert it into simple derivatives, which are then turned into biogas or bioethanol [4]. Cellulolytic enzymes play an essential part in the natural biodegradation process, in which cellulolytic fungi and bacteria effectively break down plant lignocellulosic materials. In industry, cellulases are useful in sugars and ethanol production $[5,6,7]$. Fungal cellulases are inducible enzymes that are usually excreted into the environment and depend on cellulose type (crystalline or amorphous) [8.9]. Several fungal strains belonged to many genera have been documented for their role in the cellulose degradation process in various environments including Aspergillus sp., Trichoderma sp. Chaetomium sp., Acremonium sp., Penicillium sp., Phanerochaete sp., Sporotrichum sp., Fusarium sp. Talaromyces sp., and Rhizopus sp. [8, $10,11]$. Therefore, As a result, the current work attempted to optimize cellulase production from a fungal strain and its use in the bioconversion of Hassawi rice straw residues into glucose for the manufacture of bioethanol (Scheme 1). The protein 3D structure was generated via in silico homology modeling based on amino acid sequence and determination of binding active sites and target ligands were carried out on the I-TASSER algorithm for validation of our in-vitro study.

\section{Material And Methods}

\section{Marine sample collection}

Marine samples were collected from the red sea, Jeddah, Kingdom of Saudi Arabia, 2020. All samples were collected, photographed, coded, and kept in sterile tubes in a refrigerator at $4^{\circ} \mathrm{C}$ for further analysis.

\section{Rice straw}

The Hassawi rice straw was collected from Eastern Province, Al-Ahsa, Kingdom of Saudi Arabia, scheme 1 describes the whole objectives of the project, and one of these objectives was to produce bioethanol from rice straw wastes (highlighted in green)

\section{Isolation of endophytic fungi}

Isolation of fungi from the Marine sponge was carried out through surface sterilization of the sponge surface was performed as described by Anand et al. [12], followed by cutting the sponge tissues into small pieces and plated on potato dextrose media for isolation of fungi. The plates were incubated at $30^{\circ} \mathrm{C}$ for 14 days until the appearance of any fungal growth. The fungal colonies were picked out, purified, and maintained at $-4^{\circ} \mathrm{C}$

\section{Qualitative screening of cellulolytic activity}

The isolated fungi were qualitatively screened for their cellulolytic activity as described by Wang et al. [13] using the following medium (g/l) $\mathrm{NaNO}_{3}(2.0), \mathrm{K}_{2} \mathrm{HPO}_{4}(1), \mathrm{MgSO}_{4}(0.5), \mathrm{KCL}(0.5), \mathrm{FeSO}_{4}(0.01)$ 
Cellulose (10.0). agar (20.0); and distilled water $1000 \mathrm{ml}$ and pH 6.0. After 72 hours of incubation, the plates were stained with $1 \%$ Congo red for 20 minutes at room temperature. The plates were then carefully cleaned with a $1 \mathrm{M} \mathrm{NaCl}$ solution. Cellulase activity was determined as a clear zone surrounding the fungal colonies. The contrast was improved further by soaking the plates in $5 \%$ acetic acid for 1 to 2 minutes and then washing away the excess acid with distilled water. The fungus that showed good clearance beyond the areas of its growth was then chosen for future investigation. The detection of cellulases activity was also carried out using iodine solution ( $1 \%$ iodine crystals and $2 \%$ potassium iodide), formation of a bluish-black combination with cellulose or CMC in 15 minutes, demarcating a clear zone around the fungal colonies [14].

\section{Quantitative screening of cellulolytic fungi}

Cellulase activity was quantified by culturing cellulose-positive fungal isolates that shown a positive cellulolytic activity in broth culture medium previously mentioned in the qualitative screening section [15]. The initial $\mathrm{pH}$ of the prepared medium was 5.0. and after inoculation, cultures were incubated at $30^{\circ} \mathrm{C}$ (150rpm) for 3, 6, and 9 days. At the end of incubation, fungal mycelia were eliminated from the broth culture and culture filtrate was used to measure the cellulase activities including FP-ase, CMC-ase, $\beta$ glucosidase

\section{Assay of cellulolytic enzymes activity}

The cellulase activity was measured following the method of Mandels et al. [16]. To measure the FP-ase activity, $1 \mathrm{ml}$ of $0.05 \mathrm{M}$ citrate buffer $(\mathrm{pH} 4.8)$ was added to $25 \mathrm{mg}$ of Whatman filter paper no.1. To this 0.5 $\mathrm{mL}$ of filtrate was added at $50^{\circ} \mathrm{C}$ for 1 hour. Carboxymethyl cellulose (CMC-ase) was also assayed by mixing $1 \mathrm{~mL}$ enzyme solution with $1 \mathrm{~mL}$ of $1 \% \mathrm{CMC}$ diluted in $0.05 \mathrm{M}$ sodium citrate buffer $\mathrm{pH}$ 4.8. The mixture was incubated at $50^{\circ} \mathrm{C}$ for one hour. To assay $\beta$-Glucosidase enzyme activity, $0.5 \mathrm{ml}$ enzyme was mixed with $0.5 \mathrm{ml}$ of $(0.05 \mathrm{M}$ citrate buffer $\mathrm{pH} 4.8)$ and $1 \%$ salicin at $50^{\circ}$. The dinitrosalicylic acid method was used to determine the amount of reducing sugars liberated in the test mixture [17]. Enzyme activity was defined as the number of micromoles of reducing sugar released per minute per milliliter of test solution (measured as glucose).

\section{Phenotypic identification of the selected fungus}

The fungal isolate was preliminarily identified using morphological features such as colony growth pattern, conidial morphology [18].

\section{Genotypic identification of the selected fungus}

The selected fungal strains were identified genetically by sequencing of the 18srRNA gene. The genomic DNA was extracted using the Qiagen DNeasy Mini Kit according to the manufacturer's instructions. The PCR reaction mixture was as follows: (10 mM dNTPs mixture, $1 \mu \mathrm{g}$ genomic DNA, $10 \mathrm{mM}$ dNTPs mixture, $1 \mu \mathrm{L}$ (20 uM of each primer), 2 units of Taq DNA polymerase enzyme, and $10 \mu \mathrm{L} 5 \mathrm{X}$ reaction buffer). The amplification reactions were carried out using two primers ITS1 (5- TC GTAGGTG $\forall \mathbb{C} T G C G$ - 3)/ ITS4 (5- $T \mathbb{C} T \mathbb{C} G C T A T G A T A T G C$ - 3) the following PCR thermal profiles: denaturation step at $94^{\circ} \mathrm{C}$ for 5 
min followed by 35 cycles of $94^{\circ} \mathrm{C}$ for $30 \mathrm{sec}, 55^{\circ} \mathrm{C}$ for $30 \mathrm{sec}, 72^{\circ} \mathrm{C}$ for $90 \mathrm{sec}$, and a final extension step of $72^{\circ} \mathrm{C}$ for $5 \mathrm{~min}$. The amplified products were examined by electrophoresis and sequenced in Macrogen Companies, South Korea. The sequence produced was analyzed by using BLASTN program, to study the similarity and homology of the 18S rRNA gene sequences with the similar existing sequences available at the NCBI database

\section{Production of cellulase enzymes via solid-state fermentation (STF) on alkali-treated rice straw}

The cellulase enzymes production was carried out using the solid-state fermentation (STF) method. Briefly, 60 grams of alkali pretreated rice were inserted into $1 \mathrm{~L}$ Erlenmeyer flasks. The mineral salt liquid medium was used as a moistening agent with \% of ( $5 \mathrm{~mL}$ for each gram of substrate). After mixing a separately autoclaved substrate and a mineral salt, the flask was inoculated with $20 \mathrm{~mL}$ from Aspergillus sp. NAS51 spore suspension containing $1 \times 10^{5}$ spores $/ \mathrm{mL}$. After inoculation, the flasks were incubated at $28^{\circ} \mathrm{C}$ under static conditions for 10 days

\section{Optimization of Aspergillus sp. NAS51 cultural condition for cellulase production}

\section{Effect of optimal pH and temperature on cellulase production}

The optimum pHwas measured by growing the fungus Aspergillus sp. NAS51 in solid-state fermentation at different $\mathrm{pH}$ values starting from $3,4,5,6,7,8$, and 9 at $28^{\circ} \mathrm{C}$ for 10 days. additionally, the optimum temperature was also measured by incubating the cultural media at various temperatures ranging from $20,25,30,35$, and $40^{\circ} \mathrm{C}$.

\section{Effect of moisture content on cellulase production}

The effect of different moisture content was studied by preparing media with different moisture content in a range of $(50,60,70,80 \%)$.

\section{Effect of incubation period on cellulase production}

The effect of the incubation period on cellulase enzyme production was studied by incubation of the inoculated cultural flasks at different incubation times $(1,3,5,7,9,11,13,15,17$, and 19 days.

\section{Effect of different nitrogen sources and $\mathrm{K}_{2} \mathrm{HPO}_{4}$ cellulase production}

The effect of different nitrogen sources has been studied by assessing the activity of cellulase enzyme produced by the cultivation of Aspergillus sp. NAS51 on rice straw with moisture content supplemented with different nitrogen sources such as (AmmoniumSulfate, Urea, Ammonium nitrate Diammonium 
phosphate). Furthermore, Optimization of $\mathrm{K}_{2} \mathrm{HPO}_{4}$ in the medium was carried out by adding it in a range of $1-5 \mathrm{~g} / \mathrm{L}$ at five levels

\section{Characterization of Aspergillus sp. NAS51 cellulase enzyme Effect of temperature and pH on Aspergillus sp. NAS51 cellulase enzyme}

The optimal and temperature of the cellulase enzyme were performed by measuring cellulase activity at different temperatures 30 to $80^{\circ} \mathrm{C}$. additionally, the effect of $\mathrm{pH}$ on the activity was performed under various $\mathrm{pH}$ buffers, starting from Mcllvainebuffer $(50 \mathrm{mM}, \mathrm{pH} 4-6)$, phosphate buffer (50 mM, pH 7-8), and carbonate buffer (50 mM, pH 9-10).

\section{Effect of temperature and pH on aspergillus sp. NAS51 cellulase enzyme}

To measure the cellulase enzyme stability toward temperature and $\mathrm{pH}$, the cellulase enzyme was incubated at different pH buffers between 4.0 and 10.0 for $15 \mathrm{~h}$ at $4^{\circ} \mathrm{C}$. the enzyme was also incubated at different temperatures profiles from $\left(30-90^{\circ} \mathrm{C}\right.$ for $\left.1 \mathrm{~h}\right)$ and the residual activity was determined every 20 $\min$.

\section{Cellulase gene partial sequencing}

The DNA was extracted through EasyPure plant DNA isolation kit, gene amplified using PCR specific primers (Forward primer 1 'AGTGCGGTGGTATCAACTGG', Reverse primer 1 'AGTCGTTCTGGACCTTGCAG', Forward primer 2CACCCAGGTTGAGATTGCCT, Reverse primer 2 'CCAGTTGATACCACCGCACT', Forward primer 3 'ATCTTCGTCGAGGGTAACGC', Reverse primer 3 'TTCTCGAGGATGGGCAGGTA' forward primer 6CTTCCCTAGCGGTGATGCTT, Reverse primer 6 AGCGACGCTGGAAGAAGTAG, sequenced and aligned with other identified genes in the Gene bank database using an online BLAST tool to determine the similarity score (http://www.blast.ncbi.nlm.nih.gov/Blast). The software SnapGene viewer, version 3.1.2.156 has been used to translate the nucleotide sequence of the obtained cellulase nucleotide sequence into an amino acid sequence.

\section{Analysis of physicochemical parameters of cellulase enzyme}

To compute the physicochemical parameters of the cellulase enzyme, ExPASy'sProtParam program was used. These properties can be derived from a protein sequence which includes parameters such as molecular weight (M.Wt), instability index (II), aliphatic index (AI), theoretical pl, and grand average of hydropathicity (GRAVY). the instability index provides an approximation of our protein's stability. A protein with an instability index less than 40 is projected to be stable; a score greater than 40 indicates that the protein may be unstable [19]. 


\section{Construction of the 3D Enzymes Structure by Homology Modeling}

The amino acid sequences of the aspergillus sp. NAS51 enzymes were submitted to the SWISS-MODEL and the 3D structure of the cellulase enzymes was automatically generated by first transferring conserved atom coordinates provided by the desired template alignment [20]. Endo $\beta$-1,4-glucanase from $B$. licheniformis was utilized as a template to perform the homology modeling of the fungal cellulase structure. The enzyme models were obtained as a PDB file and the model was energy minimized via Gromos96 tools in the Swiss-PDB viewer [21].

\section{Identification of the Enzymes Catalytic Residues}

The active-site residues of the cellulase enzyme were predicted using the I-TASSER web-server (https://zhanggroup.org/I-TASSER/). I-TASSER web-server detects catalytic residues in the primary structural alignment, which was then viewed in PyMOL. According to a previously reported approach, the probable active-site residues were superimposed on a template structure in this case [22]. $\mathrm{COACH}$, a metaserver, was then used to predict the protein-ligand interaction site. To construct the final ligand binding site predictions, the predictions were merged with data from the COFACTOR, FINDSITE, and ConCavity analyses.

\section{Enzymatic saccharification}

Enzymatic saccharification of alkali-treated rice straw was carried by mixing 2 grams of pretreated rice straw with $100 \mathrm{ml}$ of $0.05 \mathrm{M}$ citrate buffer at pH $4.8(1.20 \mathrm{U} / \mathrm{mL}) 250 \mathrm{~mL}$ Erlenmeyer flasks with a magnetic bar. The mixture was incubated at $50^{\circ} \mathrm{C}$ for $24 \mathrm{~h}$ with agitation. During the incubation period, samples were taken at 4, 8, 16, and 24 hour intervals. The reaction was stopped by adding $3 \mathrm{~mL}$ of $1 \% 3,5$ dinitrosalicylic acid (DNS) reagent to $1 \mathrm{~mL}$ of the reaction mixture and heating it for 10 minutes. In these assays, reducing sugars were calculated calorimetrically using glucose as a standard, as described by [17]. Cellulase activity is defined as the quantity of enzyme that releases 1 mol reducing sugars (measured as glucose) per $\mathrm{mL}$ per minute.

\section{High-performance liquid chromatography (HPLC)}

To confirm the presence of glucose and other reducing sugars, samples were withdrawn at different times and the composition of sugar mixtures was then analyzed by high-performance liquid chromatography (HPLC). The authentic reference sugars were determined using Agilent Technologies 1100 series liquid chromatography equipped with an autosampler and a refractive index detector. SCR-101 N was the analytical column. The mobile phase was deionized water, with a flow rate of $0.7 \mathrm{ml} / \mathrm{min}$. The oven temperature was set to 40 degrees Celsius. Samples were diluted and filtered through a 0.22- $\mu \mathrm{m}$ Nylon membrane before injection to remove proteins that could interfere with the analysis [23].

\section{Ethanol production and estimation}


The bioethanol fermentation process was performed in liquid state fermentation. The seed broth of the Saccharomyces cerevisiae was prepared by inoculation of a loop of Saccharomyces cerevisiae in yeast extract peptone dextrose broth medium (YEPD) and incubation of the culture media for $24 \mathrm{~h}$ at $28^{\circ} \mathrm{C}$ and

(200 rpm). until the growth reached $5 \times 10^{8} \mathrm{CFU} / \mathrm{mL}$. The fermentation media composition was as follows: glucose (sugar solution generated by enzymatic saccharification of rice straw), $0.2 \mathrm{~g}$ yeast extract, and $5.0 \mathrm{~g}$ peptone were added, and the $\mathrm{pH}$ was adjusted to 5 . The medium is introduced in flasks with a capacity of $250 \mathrm{ml}$ and $100 \mathrm{ml}$ of fermentation media. To sterilize the flasks, they were autoclaved. Following sterilization, the flasks were inoculated with $1 \mathrm{~mL}$ of saccharomyces seed broth cultures. The inoculated flasks were incubated at $30^{\circ} \mathrm{C}$ on a rotary shaker $(200 \mathrm{rpm})$ for 7 days. After 7 days of fermentation, the ethanol content was determined. To determine the amount of ethanol produced, one $\mathrm{mL}$ of fermented wash was placed in a $500 \mathrm{~mL}$ pyrex distillation flask filled with 30 miL of distilled water. The distillation product was collected in a $50 \mathrm{~mL}$ flask containing a $25 \mathrm{~mL}$ solution of potassium dichromate (33.76 $\mathrm{g}$ of $\mathrm{K}_{2} \mathrm{Cr}_{2} \mathrm{O}_{7}$ dissolved in $400 \mathrm{~mL}$ of distilled water with $325 \mathrm{ml}$ of sulphuric acid and volume raised to 1 liter). In each sample, approximately $20 \mathrm{~mL}$ of distillate was collected, and the flasks were placed in a water bath maintained at $62.5^{\circ} \mathrm{C}$ for 20 minutes. The flasks were brought to room temperature and the volume was increased to $50 \mathrm{~mL} .5 \mathrm{~mL}$ of this were diluted with $5 \mathrm{~mL}$ of distilled water before being measured with a spectrophotometer at $600 \mathrm{~nm}$ [24]. Under comparable conditions, a standard curve was produced by using a standard solution of ethanol containing 2 to 14 percent $(\mathrm{v} / \mathrm{v})$ ethanol in distilled water, and the ethanol concentration of each sample was estimated [25].

\section{Results And Discussion}

Marine sample collection and fungal isolation

Collection of marine sponges were collected from the red sed of Jeddah, KSA. Eight endophytic fungal strains coded as (NAS25, NAS26, NAS30, NAS42, NAS46, NAS49, NAS51, NAS52) have been isolated using potato dextrose media.

Screening of fungi for cellulolytic enzymes activity

The isolated fungal isolates were screened quantitatively for their ability to produces cellulases. Out of eight isolates, 3 isolates displayed positive cellulolytic activity. Fig. 1 displayed both positive

and negative cellulase endophytic fungi on plates flooded with either (a) lodine solution or (b) Congo red.

the appearance of Clear zones around the fungal colonies indicates

their ability for cellulase production. The obtained result showed that out of 8 fungal isolates only 4 isolates displayed a pronounced cellulase enzymes activity Kasana et al. [26] developed an accurate and obvious method by using Gram's iodine and Congo which gave a more rapid and highly apparent 
detection results. Several studies have been used gram iodine for the screening of cellulase-producing fungi [27].

Quantitative screening fungus cellulolytic activity

Based on the qualitative screening results, four endophytic fungal strains have been selected for further cellulase enzymes activity. The assay involved the evaluation of FP-ase, Salicinase, and CMC-ase activity. Results in Table 1 represent the data for the positive selected four fungal strains based on the qualitative screening 'formation of a clear zone on congo red and iodine plates. The strain NAS51 displayed maximum and highest cellulase activity (FP-ase, $\beta$-glucosidase (Salicinase), and CMC-ase enzymes) with activity values (FP-ase, $3.13 \mathrm{U} / \mathrm{ml}$; CMC-ase, $2.52 \mathrm{U} / \mathrm{ml}$ and $\beta$-glucosidase (Salicinase), $0.69 \mathrm{U} / \mathrm{ml}$ ). followed by NAS46, which displayed a pronounced FP-ase activity with $1.09 \mathrm{U} / \mathrm{ml}$, while it shows weak $\mathrm{CMC}$-ase activity with $0.58 \mathrm{U} / \mathrm{ml}$ and approximately no Salicinase activity. The rest two fungal strains showed low cellulase enzymes activity. Several reports have been investigated the cellulase activity of fungi. One of these reports was done by Sri Lakshmi and Narasimha [28], who investigated the cellulase enzymes production by four fungal strains, their reports showed that one isolate belonged to Aspergillus $s p$. exhibited the highest cellulases activity (FP-ase, 14.16U/ml; CMC-ase, 64U/ml and B-glucosidase, $0.014 \mathrm{U} / \mathrm{ml})$.

Table 1 Quantitative screening fungal cellulolytic activity

\begin{tabular}{|c|c|c|c|c|c|c|c|}
\hline \multirow{2}{*}{$\begin{array}{l}\text { Isolate } \\
\text { code }\end{array}$} & \multirow{2}{*}{$\begin{array}{l}\text { Incubation } \\
\text { period } \\
\text { (days) }\end{array}$} & \multirow{2}{*}{$\begin{array}{l}\text { Cultural } \\
\text { Initial } \\
\text { pH }\end{array}$} & \multirow{2}{*}{$\begin{array}{l}\text { Cultural } \\
\text { Final } \\
\text { pH }\end{array}$} & \multirow{2}{*}{$\begin{array}{l}\text { Total protein } \\
(\mathrm{mg} / \mathrm{ml})\end{array}$} & \multicolumn{3}{|c|}{ Enzyme activity (U/ml) } \\
\hline & & & & & $\begin{array}{l}\text { FP- } \\
\text { ase }\end{array}$ & $\begin{array}{l}\text { CMC- } \\
\text { ase }\end{array}$ & Salicinase \\
\hline NAS26 & 7 & 6.2 & 4.5 & 1.20 & 0.21 & 0.26 & 0.19 \\
\hline NAS30 & 7 & 6.2 & 3.2 & 0.95 & 0.125 & 0.35 & 0.16 \\
\hline NAS46 & 7 & 6.2 & 3.4 & 1.06 & 2.09 & 0.58 & 0.13 \\
\hline NAS51 & 7 & 6.2 & 4.2 & 1.36 & 3.13 & 2.52 & 0.69 \\
\hline
\end{tabular}

Identification of cellulolytic fungus

Phenotypic identification

The fungus colonies are fast-growing, Colonies reaching $3-4 \mathrm{~cm}$ diameter in 7 days at $28^{\circ} \mathrm{C}$, on Czapek, yellow to buff with brown margin, zonate, reverse brown. the conidial heads are radiate. The Conidiophore size is $9.0 \mu \mathrm{m}$ in diameter. The vesicle is globose with a diameter of $26.0 \mu \mathrm{m}$. The primary streigmata7.9 $X 3.0 \mu \mathrm{m}$, secondary sterigmata was $5.5 \times 2.2 \mu \mathrm{m}$. The conidia are spherical with $3.0 \mu \mathrm{m}$ in diameter. The morphological examination of the selected fungus confirmed that the isolated microbe belongs to Aspergillus sp. as shown in Fig. 2.

Genotypic identification 
18S ribosomal DNA (rDNA)-based identification of selected fungus NAS51 considers as an accurate tool to confirm and to identify fungi. The $18 \mathrm{~S}$ rRNA gene was extracted, sequenced, and analyzed by alignment of the obtained sequence with identified sequences deposited in the GeneBank database using BLAST tool to identify the similarity score and to calculate the statistical significance of the matches http://www.blast.ncbi.nlm.nih.gov/Blast. The result established a very close similarity of the obtained sequence with aspergillus sp. with $100 \%$ homology and identity. The phylogenetic analysis and the tree were composed using the Maximum Composite Likelihood method (Fig. 3) by the MEGAX program according to Kumar et al. [29]. Based on the analysis of the DNA sequence and the morphological characteristics of the NAS51 isolate, the strain was identified as Aspergillus sp. NAS51 and deposited in GenBank with accession no. MZ665462.1

Alkali Pre-treatment of rice straw

Pretreatment with $\mathrm{NaOH}(1.5 \%)$

To remove the free non-structural sugars before the pre-treatment step, the rice straw was washed with hot deionized water $\left(80^{\circ} \mathrm{C}\right)$ then dried in the oven at $45^{\circ} \mathrm{C}$. Rice straw was pretreated with $\mathrm{NaOH}(1.5 \%)$ at $121^{\circ} \mathrm{C}$ and 15 psi pressure for $1 \mathrm{hr}$., at the ratio of $1: 10$ to substrate and $\mathrm{NaOH}$ solution. The pretreated rice straw was washed with tap water until the $\mathrm{pH}$ of the filtrate reached 6 . The washed straw was dried at $60^{\circ} \mathrm{C}$ overnight to constant weight and stored at room temperature for further use (Fig. 4). Table 2 showed the chemical constituents of untreated and chemically pretreated rice straws and weight loss after the alkali pretreatment process.

Table 2 Chemical composition of untreated and alkali-treated rice straw.

\begin{tabular}{|lll|}
\hline Composition & \multicolumn{2}{l|}{ Percentage (\%) } \\
\cline { 2 - 3 } & untreated Rice straw & $\begin{array}{l}\text { Alkali }(\mathrm{NaOH}) / \\
\text { autoclaved Rice straw }\end{array}$ \\
\hline Lignin & 22.25 & 7.50 \\
\hline Hemicellulose & 26.23 & 15.02 \\
\hline Cellulose & 30.25 & 50.12 \\
\hline Ash & 9.26 & 15.20 \\
\hline Loss in weight & -- & 25.00 \\
\hline
\end{tabular}

Cellulase production by Aspergillus sp. NAS51 via solid-state fermentation and optimization of cultural condition

The strain NAS51 which displayed the highest FP-ase and CMC-ase activity was cultivated on alkali pretreated rice straw and mineral salts as moisture content, the activity was assessed and results showed that at $\mathrm{pH} 6$ and temperature 28 the cellulase enzyme activity of the Aspergillus sp. NAS51 using alkali 
pretreated rice straw as a substrate under SSF.Extraction of cellulase enzymes was carried out using 0.1 $\mathrm{M}$ citrate buffer $\mathrm{pH} 4.8$, after the addition of $100 \mathrm{ml}$ of the buffer to each flask, the mixture was put on a rotary shaker for $1 \mathrm{hr}$ at $150 \mathrm{rpm}$. After that, the enzyme was separated from the solid biomass residues by filtration.

Optimization of cellulase production

Effect of $\mathrm{pH}$ on cellulase production

The effect of $\mathrm{pH}$ on cellulase enzyme production is considered one of the most effective factors that control the fungal strain growth and enzyme production, which controls the transportation of the nutrients through the cell membrane [30]. Several reports have studied the effect of $\mathrm{pH}$ of cellulase enzymes produced by fungi. Some fungal cellulases were found to be produced at low $\mathrm{pH}$, while other fungi secrete their cellulases at high $\mathrm{pH}$. Results showed that Aspergillus sp. NAS51producesmaximum cellulase (FP-ase) activity at pH 7.0 with activity $(4.50 \mathrm{U} / \mathrm{mL}$ )(Figure $5 a)$. the obtained results indicate that, Aspergillus sp. NAS51 produces neutral cellulases. This result is in agreement with a study conducted by Raghuwansh et al. [31] on the mutant strain of Trichoderma asperellum RCK2011 which produces cellulases at a $\mathrm{pH}$ range, 4.0-10.0.

Effect of temperature on the production of cellulase enzyme by Aspergillus sp. NAS51

The optimum temperature for the production was measured by incubating the cultural media inoculated with Aspergillus sp. NAS51 at different incubation temp. results in Fig. 5b represent the optimum incubation temperature for maximum cellulase enzyme production. Results revealed that $30^{\circ} \mathrm{C}$ is the suitable temperature needed to reach the maximum production at $\mathrm{pH} 7$ for ten days. The obtained results are in agreement study conducted on Fusarium dimerum and Rhizopus oryzae [32]. Effect of moisture content on cellulase enzyme production by Aspergillus sp. NAS51

Moisture content is an important element for successful enzyme production in the solid-state fermentation process. The increase in moisture level in the SSF process will lead to undesirable results. This fact could be related to the fact that moisture cause swelling of the substrate and makes it easier to be utilized by the organism. low moisture level will be insufficient for microorganisms to solubilize the substrate. While at higher moisture content will lead to a reduction in substrate porosity, and this will limit the availability of oxygen for fungus and consequently will reduce the fungus growth, metabolism, and enzyme production [ref]. Therefore, the influence of moisture content on cellulase enzyme production has been investigated. The results in Fig. (5c) showed that the most suitable initial moisture ratio was $70 \%$ as greatly enhanced the production cellulase (FPase) to be $4.25 \mathrm{U} / \mathrm{mL}$. Abdullah et al. [33] found that the optimum moisture content for Aspergillus niger ITBCCL74, when grown in rice straw, was 70\%. Effect of incubation period on cellulase enzyme production by Aspergillus sp. NAS51

Fig. (5d) showed that the maximum cellulase activity was obtained after 11 days of incubation at $30^{\circ} \mathrm{C}$, moisture level $70 \%, \mathrm{pH} 7$. Several reports have evaluated the effect of incubation time on cellulase production under SSF. The maximum cellulase activity by Fusarium dimerum and Rhizopus oryzae was 
obtained after 9 and 11 days, respectively [32]. While Jafari et al. [34] achieved maximum enzyme activity from $A$. niger mutant after 10 days.

Effect of nitrogen source on the production of cellulose

Nitrogen elements consider as vital precursors for the construction of protein or enzyme. Fig. (6a) showed the effect of different nitrogen sources in mineral salt medium cellulase (FP-ase) enzyme activity. Results showed that the fungus displayed maximum cellulase activity with $5.62 \mathrm{U} / \mathrm{mL}$ when urea was used as a nitrogen source.

Effect of $\mathrm{K}_{2} \mathrm{HPO}_{4}$ different concentration

The effect of $\mathrm{K}_{2} \mathrm{HPO}_{4}$ different concentrations was also studied by adding $\mathrm{K}_{2} \mathrm{HPO}_{4}$ in a range starting from 1 to $5 \mathrm{~g} / \mathrm{L}$. The maximum cellulase activity was achieved at a concentration of $2 \mathrm{~g} / \mathrm{L}$. while the activity decreased gradually with increasing $\mathrm{K}_{2} \mathrm{HPO}_{4}$ concentration (Fig. 6b).

Characterization of crude cellulase enzyme

Optimum $\mathrm{pH}$ and $\mathrm{pH}$ stability

Cellulase enzyme fromAspergillus sp. NAS51 exhibited optimum pH of 7 (Fig. 7a), but it's very clear that Aspergillus sp. NAS51enzyme can retain about $80 \%$ of its activity at $\mathrm{pH} 8$ and up to $50 \%$ at $\mathrm{pH} 9$. The result obtained showed that the enzyme could work efficiently at a wide range of $\mathrm{pH}$ from 6-10.

Fig. (7b)showed the enzyme stability after incubation with different $\mathrm{Ph}$ at $4^{\circ} \mathrm{Cfor} 15 \mathrm{~h}$. Optimum temperature and temperature stability

This cellulase enzyme showed maximum enzyme activity at $40^{\circ} \mathrm{C} \mathrm{(Fig.} 7 \mathrm{C}$ ), the activity of the enzymes decreased gradually with an increase of incubation. The cellulase enzyme was stable up to $40^{\circ} \mathrm{C}$, while it displayed up to $50 \%$ activity loss at $50^{\circ} \mathrm{C}$, and at $80^{\circ} \mathrm{C}$ the enzyme retained up to $5 \%$ of its activity whereas, it lost its activity over $70^{\circ} \mathrm{C}$ (Fig. $7 \mathrm{~d}$ ).

Cellulase gene sequencing

PCR amplicon was estimated through agarose gel electrophoresis (prepared with $0.7 \mathrm{~g}$ agarose dissolved in $1 \mathrm{X}$ of $50 \mathrm{ml}$ TAE and $1 \mu \mathrm{l}$ Ethidium bromide $1 \mu \mathrm{g} / \mathrm{ml}$ ) against DNA ladder and shows a single band opposite to 1900bps (Fig. 8). Using SnapGene software viewer version 4.1.3., this nucleotide sequence was translated into nearly 542 amino acids (Fig. 9) and the predicted protein size of enzyme resulted from amino acid polypeptide was $59.5 \mathrm{KDa}$. DNA nucleotide sequence of cellulose coding gene was blasted on NCBI using BLASTx for the amino acid sequence that resulted showed that, amino acid polypeptide sequence of our PCR amplicon have a high similarity with nine recorded mRNA polypeptide sequences from the same genus. Cellulase gene sequence showed $100 \%$ similarity with gene sequence from the same genus of the tested isolate, this gene was recorded with accession number XM_015545371.1. Kim et al. [35] noted that the expressed protein, CelM2 (novel endo-type cellulose) was purified from the cellular extracts by using Ni-NTA agarose slurry. However, the final polypeptide product of the enzyme was smaller $(60 \mathrm{kDa})$ than the predicted molecular weight of $71.5 \mathrm{kDa}$, while Wang et al. 
[36]reported that the open reading frame (ORF) for cellulase encoding gene from novel Bacillus subtilis was 1470 nucleotides and encoded a protein of 490 amino acids with a molecular weight of $54 \mathrm{kDa}$ physicochemical properties of cellulases

The physicochemical properties of Aspergillus sp. NAS51 was predicted by using ProtParam tool. The physicochemical properties (Table1) show that the molecular weight of the enzyme is (59218.20 Da). The instability index of Aspergillus sp. NAS51 cellulase is (37.96) means that the cellulase enzyme is theoretically stable. The computed Isoelectric point pl value of Aspergillus sp. NAS51 cellulase is (7.16), and the higher aliphatic index of the enzyme (87.94) indicating that Aspergillus sp. NAS51 cellulase is a thermally stable protein. Meanwhile, the negatively grand average of hydropathicity (GRAVY) values for cellulase enzyme indicated its hydrophilicity, (0.134) (Table 3).

Table 3 Summary of the ProtParam data for the Aspergillus sp. NAS51 cellulase models.

\begin{tabular}{|ll|}
\hline Details & Cellulase \\
\hline Amino acid residue & 539 \\
\hline Molecular weight & 59218.20 \\
\hline Theoretical pl & 7.16 \\
\hline Positively Charged Residue & 44 \\
\hline Negatively Charged Residue & 44 \\
\hline Total No. Atoms & 8321 \\
\hline Molecular Formula & $\mathrm{C}_{2658} \mathrm{H}_{4145} \mathrm{~N}_{701} \mathrm{O}_{803} \mathrm{~S}_{14}$ \\
\hline Aliphatic Index (\%) & 87.94 \\
\hline Instability Index (\%) & 37.96 \\
\hline GRAVY & -0.134 \\
\hline
\end{tabular}

Modeling the 3D Structures of Enzymes

The amino acid sequences of Aspergillus sp. NAS51 cellulase was subjected to homology modeling via SWISSMODELweb-server to generate the 3D structures of the cellulase enzyme [20](Waterhouse et al., 2018). The cellulase enzyme was constructed using an endo- $\beta-1,4-g l u c a n a s e$ from $B$. licheniformis (35.45\% sequence similarity). Fig. 10a illustrates the generated 3D structures of Aspergillus sp. NAS51 cellulase. Furthermore, the I-TASSERweb-server was also used to generate high-quality model predictions of 3D structure (Fig. 10b) and biological function of protein molecules.

Validation of homology model 
To evaluate the predicted 3D structure of the homology model, Ramachandran's plot of the model was constructed to determine the stereochemical quality of the protein structure by analyzing residue-byresidue geometry. The backbone conformation and overall stereochemical quality of cellulase of Aspergillus sp. NAS51 was calculated by analyzing the phi $(\Phi)$ and psi $(\psi)$ torsion angles, and the results are illustrated in the Ramachandran plots in Fig. 11.

Determination of binding site

Biological annotations of the target protein were measured by $\mathrm{COACH}$ and COFACTOR based on the ITASSER structure prediction. While COFACTOR uses structure comparison and protein-protein networks to deduce protein functions (ligand-binding sites, EC, and GO), $\mathrm{COACH}$ is a meta-server technique that collects various function annotation results (on ligand-binding sites) from the COFACTOR, TM-SITE, and S-SITE programs. According to a prediction by I-TASSER algorithm for the protein 3D structure, 4 ligands(Cellotriose,beta-D-glucose, cellobiose, and Xylopyranose) were predicted as a target for Aspergillus sp. NAS51 cellulase with five binding sites as follow; two binding site for Cellotriose (' $47,58,127,128,173,174,229,271,305,30$ ' and ' $217,218,253,254,257$ '), one binding site for beta-D-glucose ('47,58,305'), one binding site for cellobiose $\left(' 7,127,128,173,227,229,271,305^{\prime}\right)$ and one binding site for Xylopyranose ('52,58'). This outcome is in agreement with the experimental results of cellulases that preferentially hydrolyze cellulose. Fig. 12 explains the predicted binding sites in complex with ligands. Enzymatic scarification of alkali pretreatment rice straw and bioethanol production

This step aimed to hydrolyze the alkali pretreated rice straw using cellulase enzyme produced by Aspergillus sp. NAS51 produces a fermentable sugar that can be used for the production of value-added products such as bioethanol. This enzymatic conversion step is required for polysaccharides breakdown into monosaccharides such as glucose, which can be converted into ethanol and other product through a fermentation process. In the present study, Alkali treated rice straw was utilized for cellulase production by aspergillus sp. NAS51. The alkali treatment is a very important step for de-lignification, to facilitate cellulose hydrolysis by cellulase enzymes, furthermore, it permits bioconversion of glucose into ethanol by yeast. Fig. 13a showed the use of Aspergillus sp. NAS51 cellulase for scarification alkali-treated rice straw. The reducing sugars were determined using the DNS method. Fig. 15 showed that at reducing sugar were $16 \mathrm{~g} / \mathrm{L}$ and glucose: $11 \mathrm{~g} / \mathrm{L}$ when $5 \%$ of treated rice straw was used. Both total reducing sugars, as well as glucose, were found to be increased by increasing the substrate concentration (Fig. $13 \mathrm{~b})$. The hydrolysis of $3 \% \mathrm{w} / \mathrm{v}$ alkali-treated rice straw using the fungal culture filtrate of Aspergillus tamari, for 10 hours resulted in yields of $33.56 \mathrm{~g} / \mathrm{I}$ reducing sugars [37]. The enzymatic saccharification of the alkali-treated rice straw was monitored using HPLC analysis. Results in Fig. 14 confirm the presence of glucose in the sample taken after $24 \mathrm{~h}$. Bioethanol production from lignocelluloses wastes such as rice straw is considered as one of the renewable sources for biofuel production. Fig. 17 showed that after glucose fermentation in sugar solution obtained from enzymatic hydrolysis of rice straw by $S$. cerevisiae, about $6.21 \%(\mathrm{v} / \mathrm{v})(0.454 \mathrm{ml}$ ethanol/g fermentable sugars) Abedinfar et al. [38] have used Mucorindicus and Rhizopus oryzae for fermentation of rice straw and yielded ethanol up to $0.43 \mathrm{~g} \mathrm{~g}^{-1}$. His results were compared with the corresponding yield by $S$. cerevisae $0.45 \mathrm{~g} \mathrm{~g}^{-1}$. 


\section{Conclusion}

Rice straw (RS) is a lignocellulosic waste product resulted from rice harvest. Elimination of rice straw through burning in open areas makes it a significant source of pollution. In the current study, bioethanol was produced from rice straws via a saccharification process using Aspergillus sp. NAS51 as a source of cellulase enzymes through solid-state fermentation. The optimum $\mathrm{pH}$ and temperature were measured as 7 and $30^{\circ} \mathrm{C}$, the best incubation period was 11 days, moisture content was $70 \%$. The fungus displayed a maximum cellulase activity when urea was used as a nitrogen source and K2HPO4 (2g/L).

Characterization of the cellulase enzyme was also studied to determine the optimum parameters for the saccharification process. The cellulase gene has been sequenced and translated into an amino acid sequence to generate the protein 3D structure by in silico homology modeling, this helped us to determine the binding sites and biological annotations of the target protein. After saccharification, the saccharified product was measured using HPLC, fermented by Saccharomyces cerevisiae and the bioethanol yield produced from the fermentation was $0.454 \mathrm{ml}$ ethanol/g fermentable sugars. In this work, the production of bioethanol was accomplished using an environmentally friendly technique. further, studies are still needed to optimize the conditions for optimum ethanol generation from rice straw.

\section{Declarations}

\section{Data Availability}

The data used to support the finding of this study are included within the article

\section{Conflict of interest statement}

The authors declare that they have no conflict of interest.

\section{Acknowledgment}

Authors acknowledge the financial support through institutional funding program by the Ministry of Education, Saudi Arabia through the grant number IFP-KKU-2020/11

\section{References}

1. Zaman, C. Z., Pal, K., Yehye, W. A., Sagadevan, S., Shah, S. T., Adebisi, G. A., Marliana, E., Rafique, R. F., Johan, R. B.: Pyrolysis: A Sustainable Way to Generate Energy from Waste. Pyrolysis. (2017). https://doi.org/10.5772/intechopen.69036

2. Takkellapati, S., Li, T., Gonzalez, M.A.: An overview of biorefinery derived platform chemicals from a cellulose and hemicellulose biorefinery, Clean Technol Environ Policy. 20, 1615-1630 (2018) https://doi.org/10.1007/s10098-018-1568-5

3. Belal, E.B.: Bioethanol production from rice straw residues, Braz J Microbiol. 44, 225-234 (2013) https://doi.org/10.1590/S1517-83822013000100033 
4. Cesaro, A., Belgiorno, V.: Combined Biogas and Bioethanol Production: Opportunities and Challenges for Industrial Application, Energies. 8, 8121-8144 (2015) https://doi.org/10.3390/en8088121

5. Olson, L., Hahn-Hagerdahl, B.: Fermentation of lingocellulose hydrolisates for ethanol production, Enzyme Microb Technol. 18, 312-331 (1997) https://doi.org/10.1016/0141-0229(95)00157-3

6. Levy, I., Shani, Z., Shoseyov, O.: Modification of polysaccharides and plant cell wall by endo-1,4-bglucanase and cellulose-binding domains, Biomol Eng. 19, 17-30 (2002) https://doi.org/10.1016/S1389-0344(02)00007-2

7. Nunes, M.F., Cunha-Santino, M.B.D. Junior, I.B.: Xylanase and cellulase activities during anaerobic decomposition of three aquatic macrophytes, Braz J Microbiol. 42, 75-83 (2011) https://doi.org/10.1590/S1517-83822011000100010

8. Bhat, M., Bhat, S.: Cellulose degrading enzymes and their potential industrial applications, Biotechnol Adv. 15, 583-620 (1997) https://doi.org/10.1016/S0734-9750(97)00006-2

9. Ortega, N., Busto, M. D., Perez-Mateos, M.: Kinetics of cellulose saccharification by Trichoderma reesei cellulases, Int BiodeteriorBiodegradation. 47, 7-14 (2001) https://doi.org/10.1016/S09648305(00)00101-3

10. Toyama, S., Yonaha, K., Ishihara, M.: Degradation of bagasse cellulose by Acremonium sp. W-398, Sci Bul Coll AGr Univ Ryukyus. 28, 89-99(1981)

11. Teeri, T., Koivula, A.: Cellulose degradation by native and engineered fungal cellulases, Carbohydr Eur. 12, 28-33 (1995)

12. Anand, T.P., Bhat, A.W., Shouche, Y.S., Roy, U., Siddharth, J., Sarma, S.P.: Antimicrobial activity of marine bacteria associated with sponges from the waters off the coast of South East India, Microbiol Res. 161, 252-62 (2006) https://doi.org/10.1016/j.micres.2005.09.002

13. Wang, J., Ding, M., Li, Y.H., Chen, Q.X., Xu, G.J., Zhao, F.K.: Isolation of a multi-functional endogenous cellulase gene from mollusc Ampullariacrossean, Acta Biochim Biophys Sin 35, 941-946 (2003)

14. Sreedevi, S., Sajith, S., Benjamin, S.: Cellulase Producing Bacteria from the Wood-Yards on Kallai River Bank, Adv Appl Microbiol.3, 326-332 (2013) DOI: 10.4236/aim.2013.34046

15. Maki, M.L., Broere, M., Leung, K.T., Qin, W.: Characterization of some efficient cellulase producing bacteria isolated from paper mill sludges and organic fertilizers, Int J Biochem Mol Biol. 2, 146-154 (2011)

16. Mandels, M., Andreotti, R., Roche, C.: Measurement of saccharifying cellulase. Biotechnol Bioeng Symp. 1, 21-33 (1976) https://doi.org/10.1186/1754-6834-2-21

17. Miller, G.L.: Use of dinitrosalicylic acid reagent for determination of reducing sugar, Anal Chem. 31,426-428 (1959) https://doi.org/10.1021/ac60147a030

18. Khan, R., Mohamad Ghazali, F., Mahyudin, N.A., Samsudin, N.I.P., Morphological Characterization and Determination of Aflatoxigenic and Non-Aflatoxigenic Aspergillus flavus Isolated from Sweet Corn Kernels and Soil in Malaysia, Agriculture. 10, 450 (2020) https://doi.org/10.3390/agriculture10100450 
19. Guruprasad, K. Reddy, B. Pandit, M.W.: Correlation between stability of a protein and its dipeptide composition: a novel approach for predicting in vivo stability of a protein from its primary sequence, Prot Eng. 4, 155-164 (1990) https://doi.org/10.1093/protein/4.2.155

20. Waterhouse, A., Bertoni, M., Bienert, S., Studer, G., Tauriello, G., Gumienny, R., Heer, F.T., de Beer, T.A.P., Rempfer, C., Bordoli, L., Lepore, R., Schwede, T.: SWISS-MODEL: homology modelling of protein structures and complexes, Nucleic Acids Res. 2 , 296-303

(2018) https://doi.org/10.1093/nar/gky427

21. Bienert, S., Waterhouse, A., de Beer, T.A.P., Tauriello, G., Studer, G., Bordoli, L., Schwede, T.: The SWISS-MODEL Repository-new features and functionality, Nucleic Acids Res 4, 313-319 (2017) https://doi.org/10.1093/nar/gkw1132

22. Batumalaie, K., Edbeib, M.F., Mahat, N.A., Huyop, F., Wahab, R.A.: In silico and empirical approaches toward understanding the structural adaptation of the alkaline-stable lipase KV1 from Acinetobacter haemolyticus, J Biomol Struct Dyn.36, 3077-3093 (2018)

https://doi.org/10.1080/07391102.2017.1377635

23. Liu, Y., Chen, Z., Jiang, Z., Yan, Q., Yang, S.: Biochemical characterization of a novel $\beta$-galactosidase from Paenibacillusbarengoltzii suitable for lactose hydrolysis and galactooligosaccharides synthesis, Int J Biol Macromol. 104, 1055-1063 (2017) https://doi.org/10.1016/j.ijbiomac.2017.06.073

24. Caputi, A., Ueda, M., Brown, T.: Spectrophotometric determination of ethanol in wine, Am J Enol Vitic. 19,160-165 (1968)

25. Kasana, R.C., Salwan, R., Dhar, H., Dutt, S., Gulati, A.: A rapid and easy method for the detection of microbial cellulases on agar plates using gram's iodine, Curr Microbiol. 57 , 503-7 (2008) https://doi.org/10.1007/s00284-008-9276-8

26. Yoswathana, N., Phuriphipat, P., Treyawutthiwat, P., Eshtiaghi, M.N.: Bioethanol Production from Rice Straw, Energy Res J. 1, 26-31(2010)

27. Shahriarinour, M., Abd Wahab, M.N., Ariff, A., Mohamad, R.: Screening, Isolation and Selection of Cellulolytic Fungi from Oil Palm Empty Fruit Bunch Fibre, Biotechnology. 10,108-113 (2011) DOI: 10.3923/biotech.2011.108.113

28. Sri Lakshmi, A. Narasimha, G.: Production of cellulases by fungal cultures isolated from forest litter soil, Ann For Res. 55,85-92 (2012)

29. Kumar, S., Stecher, G., Li, M., Knyaz, C., Tamura, K.: MEGA X: molecular Evolutionary Genetics Analysis across computing platforms, Mol Biol Evol. 35, 1547-1549 (2018) https://doi.org/10.1093/molbev/msy096

30. Juhász, T., Szengyel, Z., Szijártó, N., Réczey, K.: Effect of pH on cellulase production of Trichoderma ressei RUT C30, Appl BiochemBiotechnol. 113, 201-211 (2004) https://doi.org/10.1007/978-159259-837-3_18

31. Raghuwanshi, S., Deswal, D., Karp, M., Kuhad, R.C.: Bioprocessing of enhanced cellulase production from a mutant of Trichoderma asperellum RCK2011 and its application in hydrolysis of cellulose, 
Fuel. 124, 183-189 (2014) https://doi.org/10.1016/j.fuel.2014.01.107

32. Ahmed, M.M., Soad, A.E., Magdi, A.E.: Cellulolytic activity of cellulose-decomposing fungi isolated from Aswan hot desert soil, Egypt, Journal of Biological Studies. 1, 35-48 (2018)

33. Abdullah, B., Maftukhah, S., Listyaningrum, E., Faradhiba, F.: Effect of some variable in cellulase production by Aspergillus niger ITBCCL74 using solid state fermentation. IOP Conf. Series Materials Science and Engineering, 316, 012066. (2018) DOI: 10.1088/1757-899X/316/1/012066

34. Jafari, N., Jafarizadeh, H.M., Hamzeh, M.M., Adibpour, M. :Optimization of UV irradiation mutation conditions for cellulose production by mutant fungal strain of Aspergillus niger through solid-state fermentation, Green process synth. 6, 333-340 (2017) https://doi.org/10.1515/gps-2016-0145

35. Kim, S.J., Lee, C.M., Han, B.R., Kim, M.Y., Yeo, Y.S., Yoon, S.H., Koo, B.S., Jun, H.K.: Characterization of a gene encoding cellulase from uncultured soil bacteria, FEMS Microbiol Lett. 282,44-51 (2008) https://doi.org/10.1111/j.1574-6968.2008.01097.x

36. Wang, L., Xiajuan, H., Ying, Z., Qingyi, M., Yulin, C.: Simultaneous cloning and expression of two cellulase genes from Bacillus subtilis newly isolated from Golden Takin (Budorcas taxicolor Bedfordi), Biochem Biophys Res Commun. 383, 397-400 (2009) https://doi.org/10.1016/j.bbrc.2009.04.027

37. Dayanandan, A., Madankumar, A., Premalatha, A.: Enzymatic hydrolysis of alkali pretreated rice straw for the enhanced production of fermentable sugars, Journal of Chemical and Pharmaceutical Research. 7, 591-597 (2015)

38. Abedinifar, S., Karimi, K., Khanahmadi, M., Taherzadeh, M.: Ethanol production by Mucor indicus and Rhizopus oryzae from rice straw by separate hydrolysis and fermentation, Biomass and Bioenergy. 33, 828-833 (2009) https://doi.org/10.1016/j.biombioe.2009.01.003

\section{Scheme}

Please see the Supplementary Files for the Scheme 1.

\section{Figures}


A
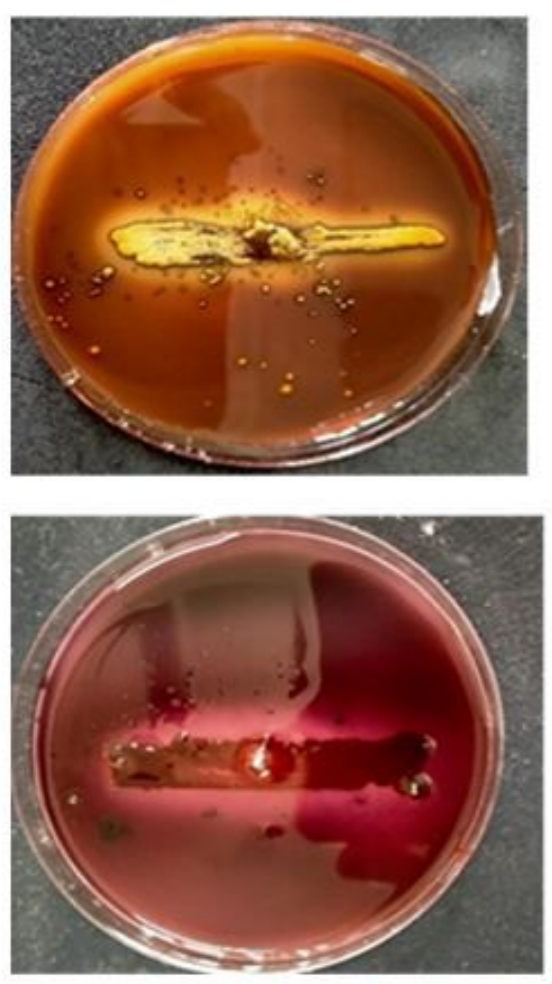

B
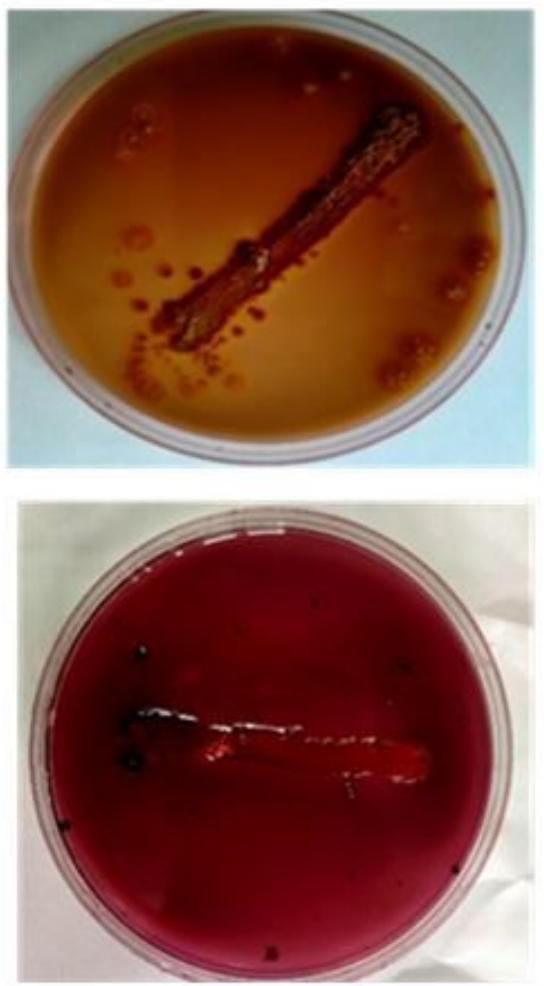

C
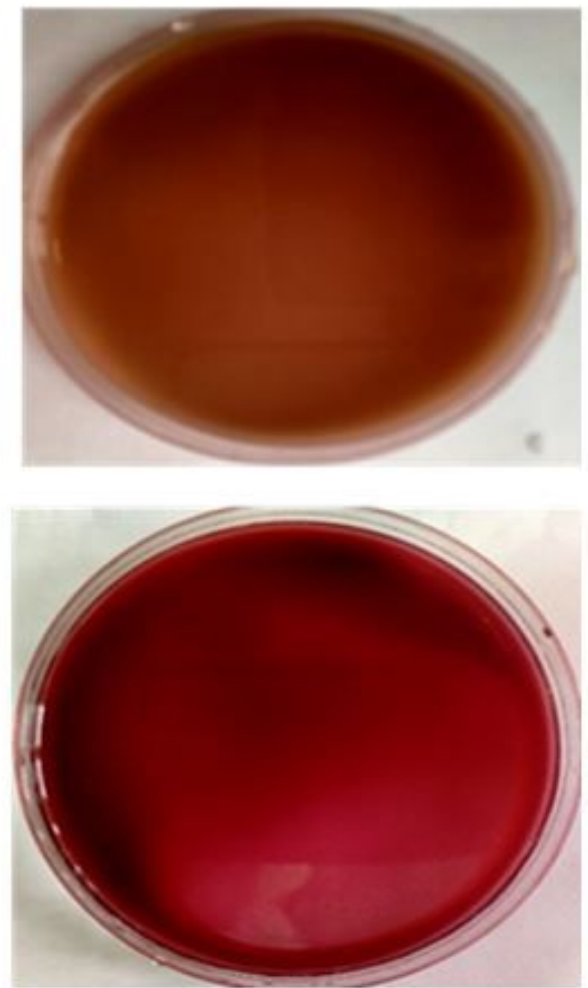

\section{Figure 1}

Qualitative screening for cellulase activity of isolates grown on agar plates containing cellulose, (A) Positive cellulolytic fungi (B) Negative cellulolytic fungi (C) Control. Upper panel: plates flooded with iodine solution, Lower panel: The plates flooded with Congo red.
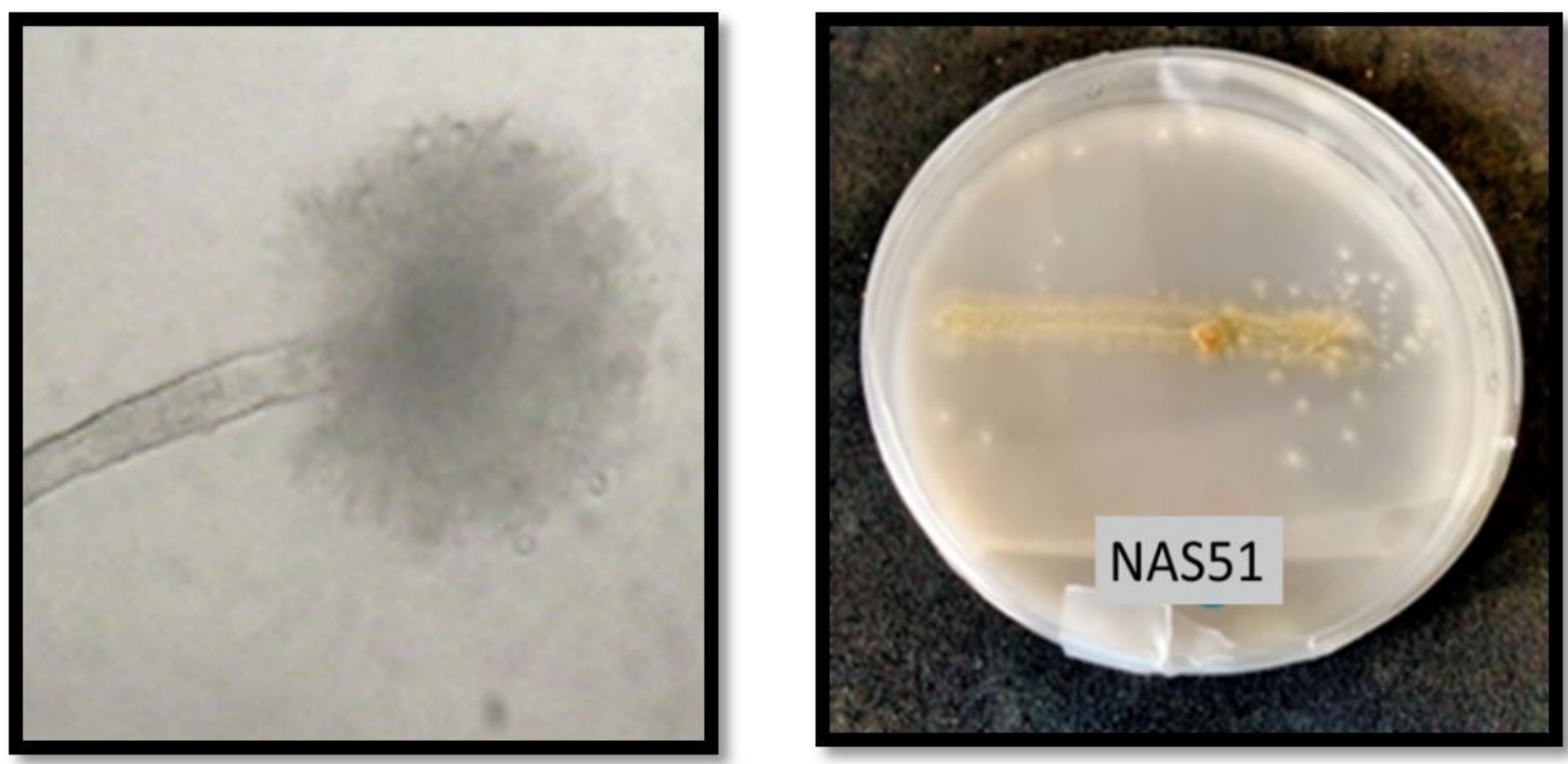


\section{Figure 2}

Micrograph showing morphological characteristics of NAS51 fungus

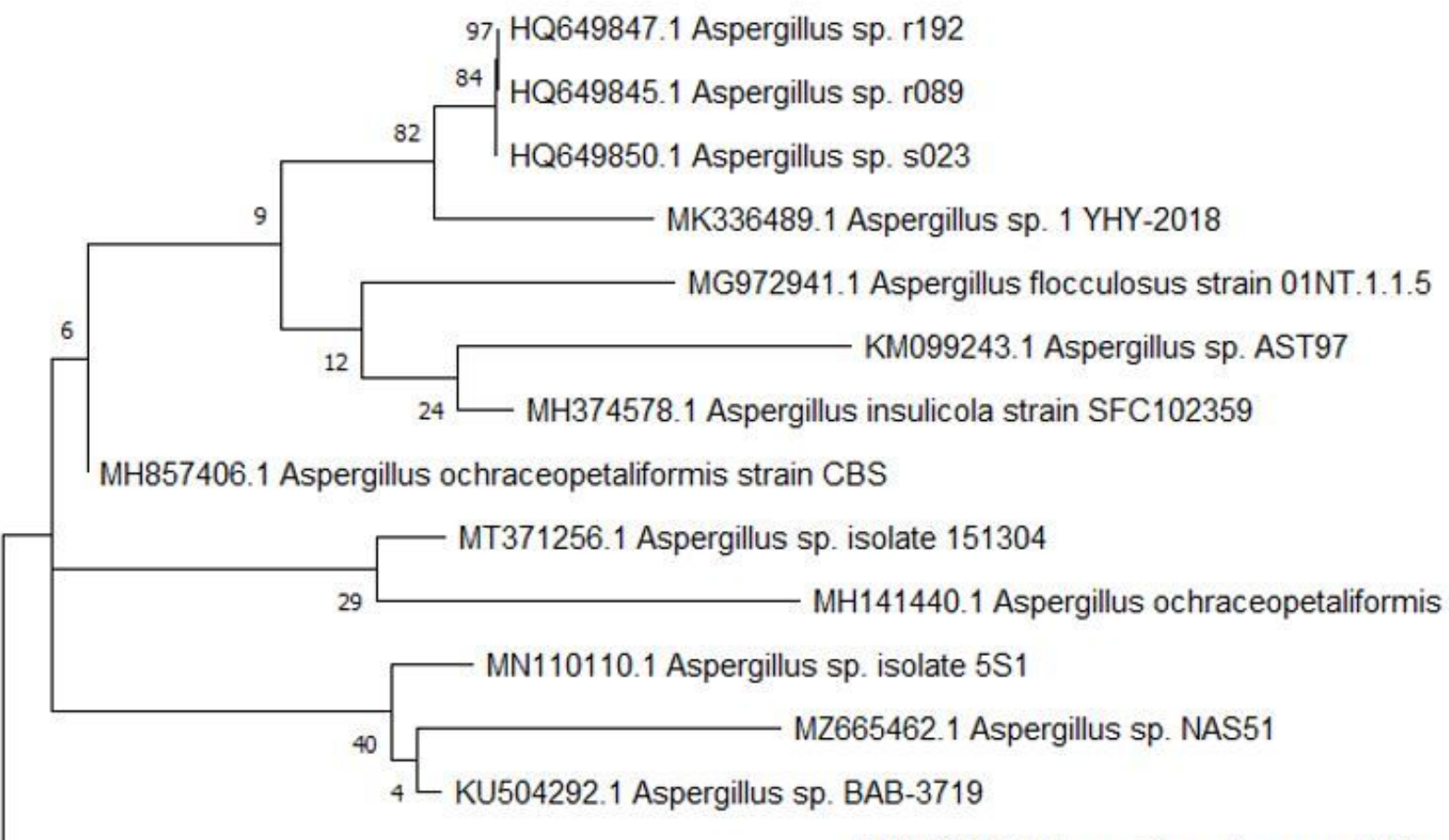

MH109740.1 Aspergillus ochraceopetaliformis strain A180326

\section{Figure 3}

Evolutionary tree of the fungus Aspergillus sp. NAS51
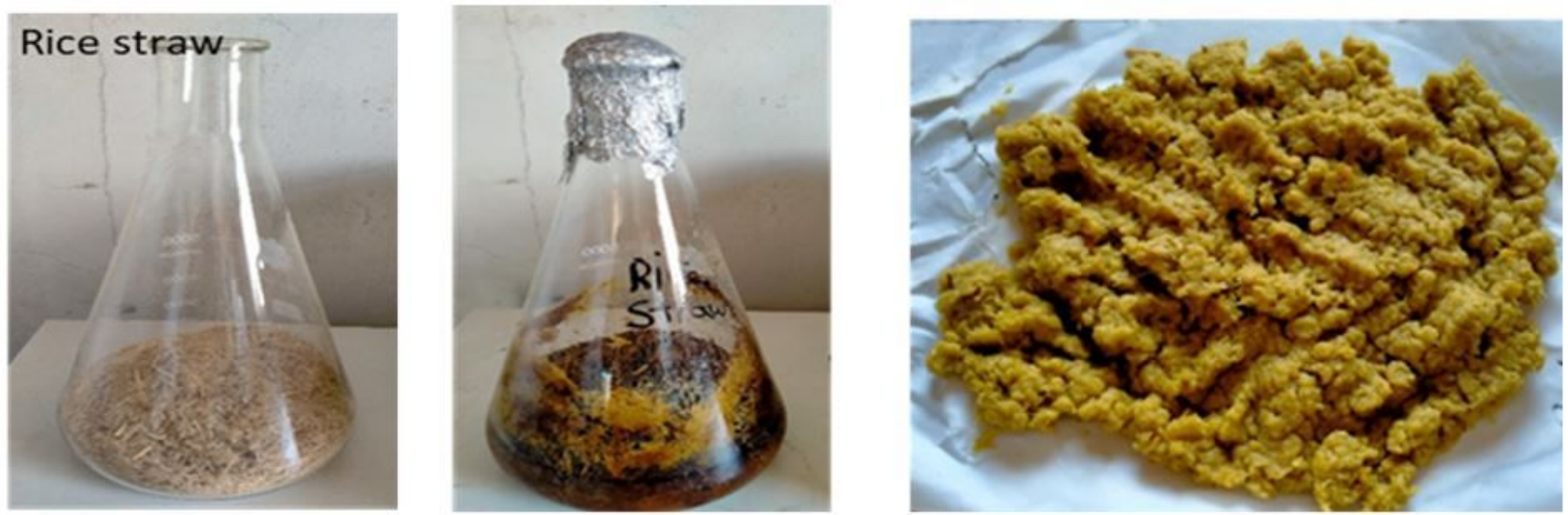

Figure 4 
Alkali pre-treatment with $\mathrm{NaOH}(1.5 \%)$ at $121^{\circ} \mathrm{C}$ and $15^{\mathrm{psi}}$ pressure for $1 \mathrm{hr}$
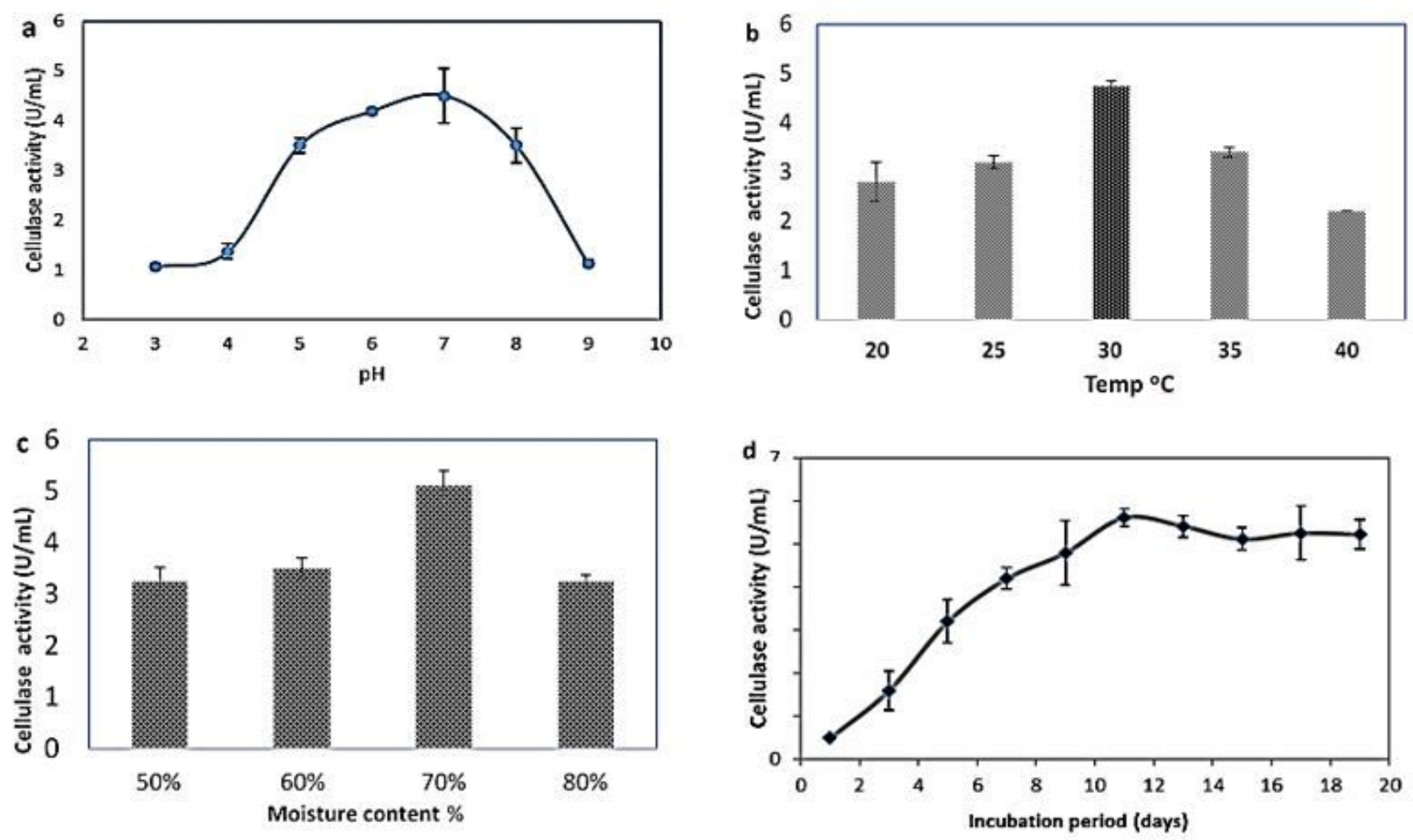

Figure 5

Effect of a) Initial $\mathrm{pH}, \mathrm{b}$ ) Temperature ${ }^{\circ} \mathrm{C}, \mathrm{c}$ ) Moisture content, and d) incubation period on the production of cellulase enzyme by Aspergillus sp. NAS51

Figure 6

Effect of a) different nitrogen source b)different concentration of $\mathrm{K}_{2} \mathrm{HPO}_{4}$ on cellulase enzyme production from Aspergillus sp. NAS51 

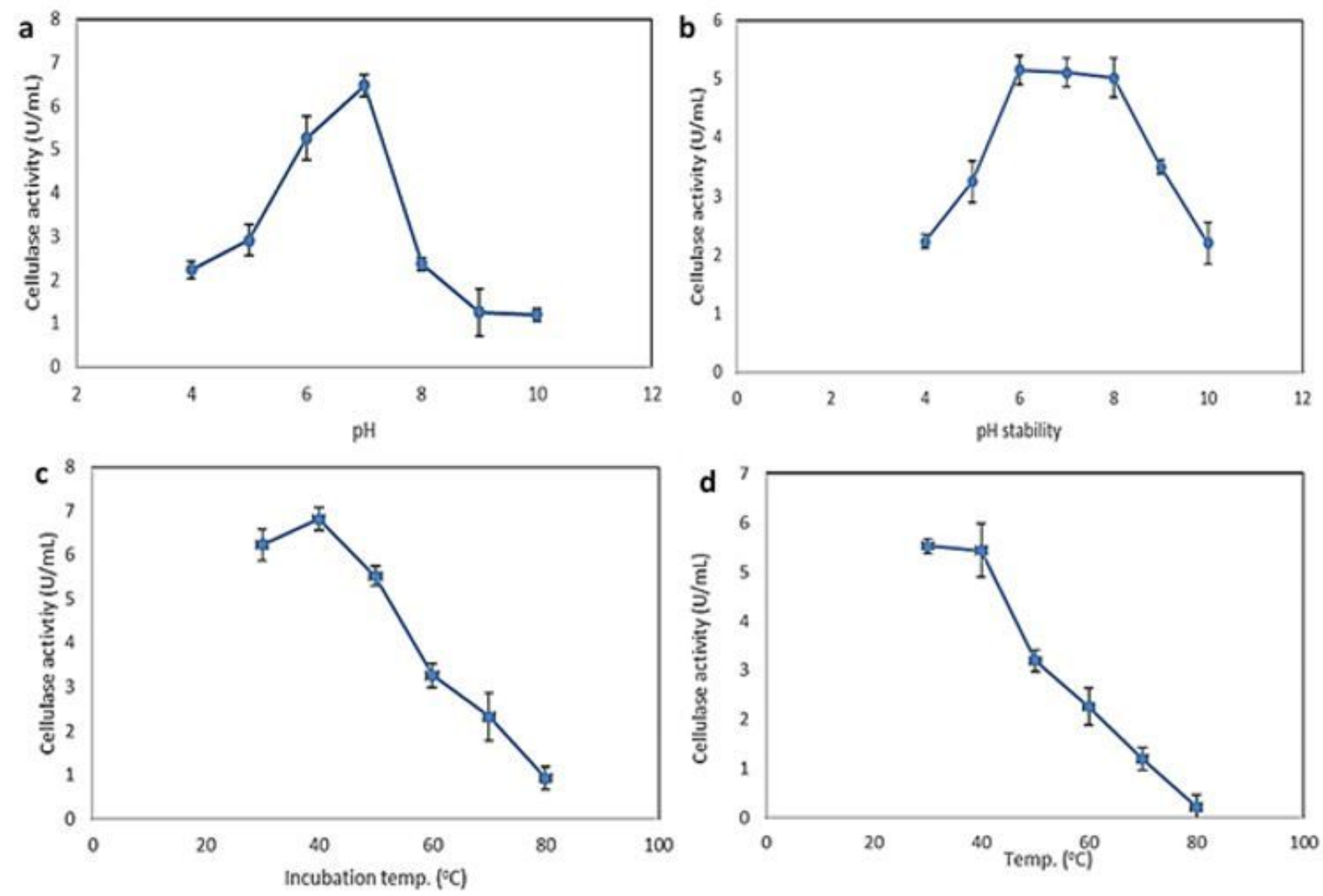

Figure 7

Characterization of crude cellulase Aspergillus sp.NAS51 include a) optimum pH b) pH stability c) Optimum temperature d)Thermal stability of cellulase enzyme

\section{Figure 8}

cellulase encoding gene molecular weight as estimated by agarose gel electrophoresis, from left to right, while $S$ for the PCR amplicon showed one band of DNA with nearly 1900 bps against 1 Kbps DNA ladder Promega 


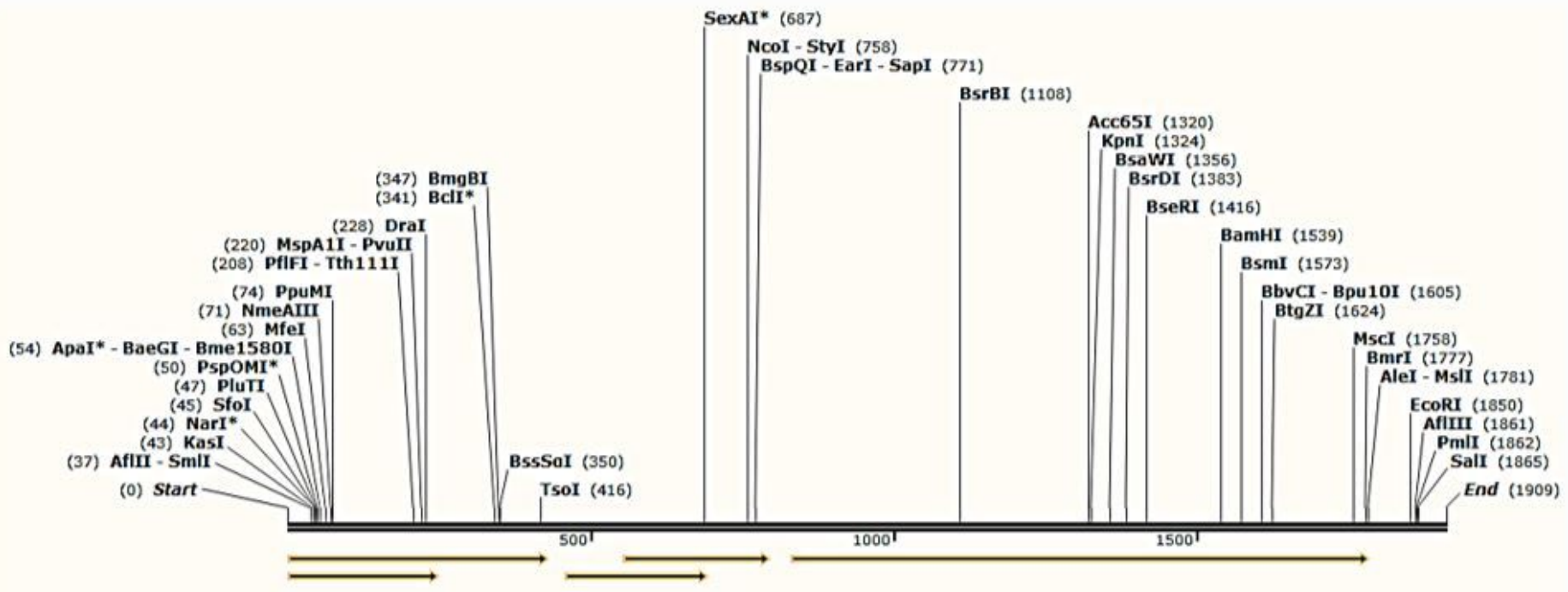

Figure 9

ORF and restriction gene map of the cellulase Aspergillus sp. NAS51

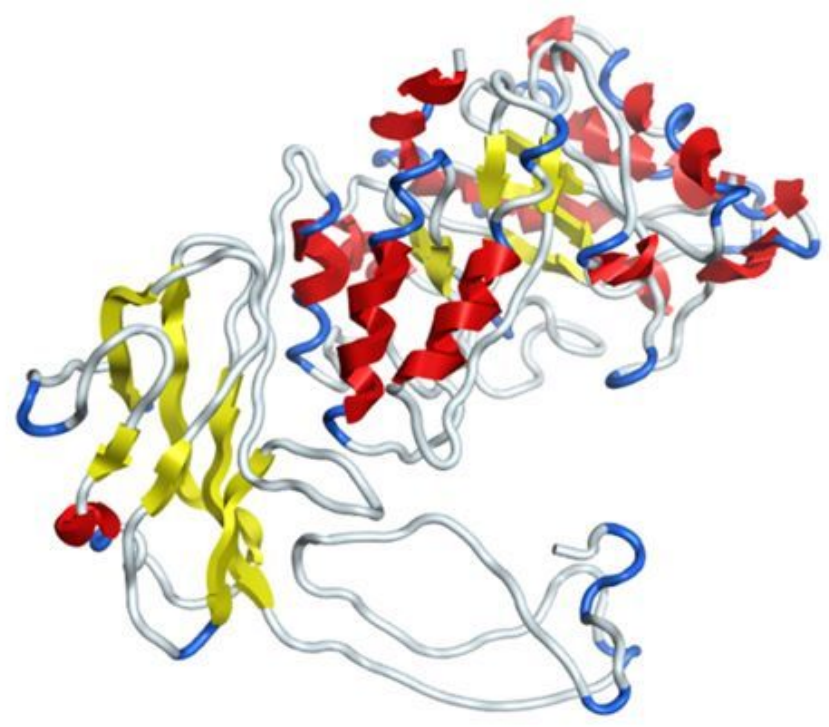

(a)

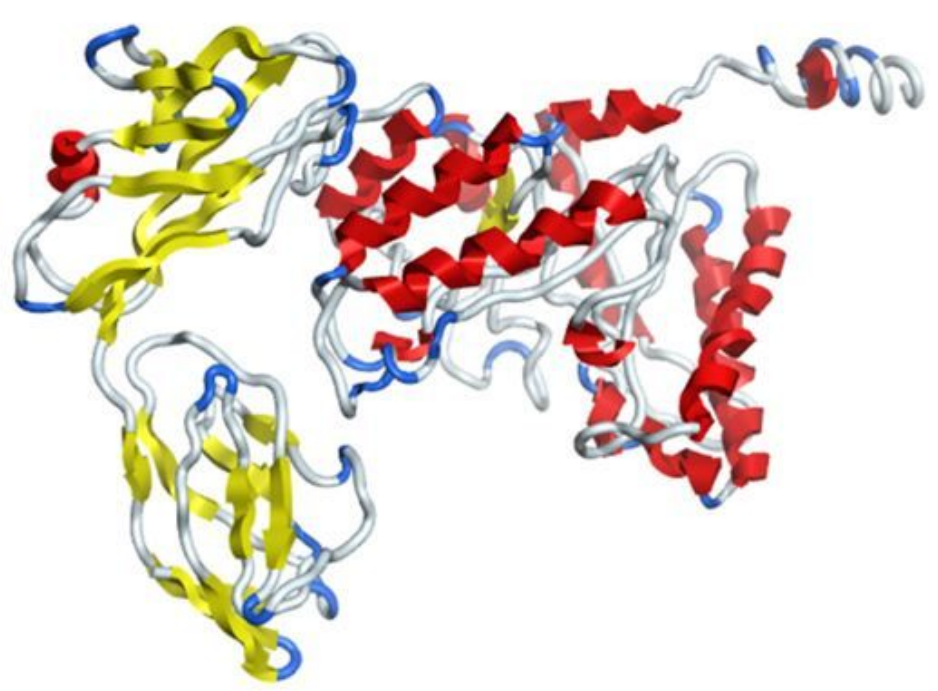

(b)

Figure 10

a) The SWISS-MODEL generated 3D structures of enzymes b) The predicted by 3D structures I-TASSER. 


\section{Figure 11}

Ramachandran's plot calculations on the 3D models of cellulase of Aspergillus sp. NAS51 computed by the SWISS-MODEL web-server.

\section{Figure 12}

Predicted binding sites in complex with ligands.
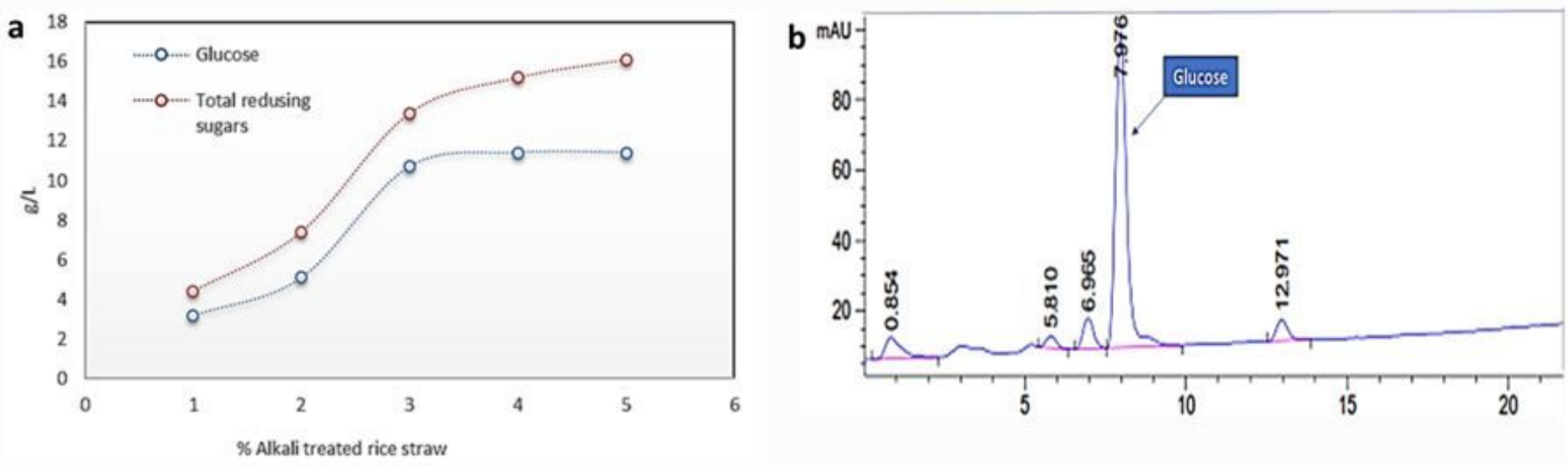

Figure 13

a)Scarification of alkali pretreatment rice straw using Aspergillus sp. NAS51crude cellulase enzyme. b) HPLC Profile of the end product resulting from hydrolysis After $24 \mathrm{~h}$. 


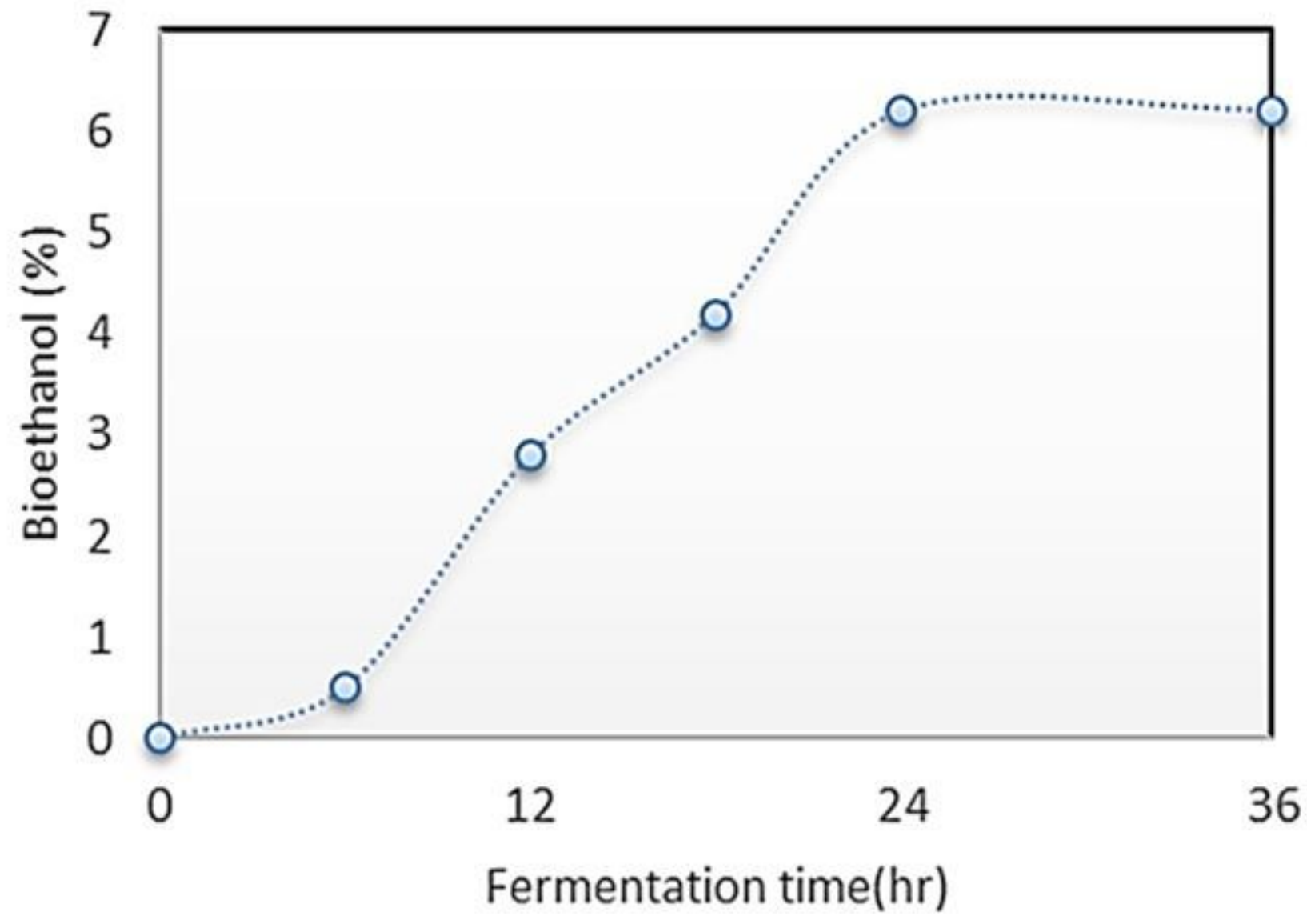

Figure 14

Ethanolic fermentation of concentrated sugary syrup obtained from enzymatic scarifications of alkali pretreatment rice straw by $S$. cerevisiae.

\section{Supplementary Files}

This is a list of supplementary files associated with this preprint. Click to download.

- graphicalabstract.docx

- scheme1.jpg 